\title{
PENGARUH PENGGUNAAN TEPUNG DAUN PEPAYA (Carica Papaya $l$ ) SEBAGAI PENGGANTI SEBAGIAN RANSUM BASAL TERHADAP PERSENTASE KARKAS DAN PERSENTASE LEMAK ABDOMEN AYAM PEDAGING
}

\author{
Marsela Surah, Florencia N. Sompie*, Youdhie H. S. Kowel, Meity R. Imbar \\ Fakultas Peternakan Universitas Sam Ratulangi Manado, 95115
}

\begin{abstract}
ABSTRAK
Penelitian ini bertujuan untuk mengetahui pengaruh penggantian sebagian ransum basal dengan tepung daun pepaya terhadap persentase dan bobot karkas, serta persentase lemak abdomen ayam pedaging. Penelitian ini menggunakan ternak ayam pedaging unsexed, umur 1 hari (DOC) sebanyak 80 ekor. Rancangan yang digunakan adalah rancangan acak lengkap (RAL) yang terdiri dari 4 perlakuan dan 5 ulangan. Susunan perlakuan percobaan sebagai berikut: $\mathrm{R}_{0}=$ $100 \%$ ransum basal (RB), $0 \%$ tepung daun pepaya (TDP), $\mathrm{R}_{1}=95 \% \mathrm{RB}+5 \% \mathrm{TDP}$, $\mathrm{R}_{2}=90 \% \mathrm{RB}+10 \% \mathrm{TDP}, \mathrm{R}_{3}=85 \% \mathrm{RB}+$ $15 \%$ TDP. Hasil penelitian menunjukkan bahwa, penggantian sebagian ransum basal dengan tepung daun pepaya memberikan pengaruh berbeda tidak nyata terhadap bobot karkas dan persentase lemak abdomen ayam pedaging. Perlakuan memberikan pengaruh berbeda sangat nyata terhadap persentase karkas. Hasil uji menunjukkan R0 berbeda sangat nyata dengan R3 tetapi berbeda tidak nyata dengan R2 dan R1. Perlakuan R1 berbeda nyata dengan R3 namun berbeda tidak nyata dengan $\mathrm{R} 2$, sedangkan antara perlakuan R2 dan R3 berbeda nyata. Berdasarkan hasil penelitian ini dapat disimpulkan bahwa penggunaan tepung daun pepaya (carica papaya l) sampai level 15\% dapat menghasilkan persentase karkas dan lemak abdomen yang baik.
\end{abstract}

*Korespondensi (Corresponding author): Email: nerysompie@unsrat.ac.id
Kata kunci: broiler, tepung daun pepaya, karkas, lemak abdomen.

\section{ABSTRACT}

THE EFFECT OF THE USE OF PAPAYA LEAVES SUBSTITUTED TO BASAL DIET ON THE PERCENTAGE OF CARCASS AND ABDOMINAL FAT PERCENTAGE OF BROILER CHICKEN. This study aims to determine the effect of papaya leaf meal substituted to basal diet on the carcass weight, percentage of carcass, and abdominal fat of broilers. This study used 80 unsexed broilers, day old chick (DOC). The experiment used a completely randomized design (CRD) consisting of 4 treatments and 5 replications. The arrangement of the experimental treatments was as follows: $\mathrm{R}_{0}$ $=100 \%$ basal diet (BD), 0\% papaya leaf meal (PLM), $\mathrm{R}_{1}=95 \% \mathrm{BD}+5 \% \mathrm{PLM}, \mathrm{R}_{2}$ $=90 \% \mathrm{BD}+10 \% \mathrm{PLM}, \mathrm{R}_{3}=85 \% \mathrm{BD}+$ $15 \%$ PLM. The results showed that partial replacement of the basal diet with with papaya leaf meal had no significant effect on carcass weight and the percentage of broiler abdominal fat. The treatment gave a very significant difference on the percentage of carcass. On carcass percentage results showed that R0 was highly significant different from R3 but not significantly different with $\mathrm{R} 2$ and $\mathrm{R} 1$. Treatment R1 was significantly different from R3 but not significantly different from $\mathrm{R} 2$, whereas between treatments R2 and R3 were significantly different. Based on the results of this study it can be stated that the use of papaya leaf meal up to level of $15 \%$ 
can produce a good proportion of carcass and abdominal fat.

Keywords: broiler, papaya leaf meal, carcasses, abdominal fat.

\section{PENDAHULUAN}

Daging ayam merupakan salah satu produk ternak yang memegang peranan penting dalam pemenuhan gizi masyarakat. Saat ini konsumen semakin selektif dalam memilih produk peternakan khususnya karkas yang berkualitas. Salah satu indikator kualitas karkas yang baik, yaitu kandungan lemak dan persentase lemak abdomen rendah. Tanaman pepaya (Carica papaya) merupakan salah satu tanaman yang dapat digunakan untuk mengurangi penimbunan lemak pada ayam pedaging. Daun pepaya merupakan bahan herbal alternatif yang dapat digunakan dalam ransum untuk memperbaiki kualitas daging. Kandungan alkaloid dan papain juga mampu menurunkan penimbunan lemak pada ayam dan tikus (Santoso dan Fenita 2015).

Menurut Ha et al., (2012) bahwa kualitas dan kuantitas karkas ayam pedaging dipengaruhi oleh kuantitas dan kualitas ransum. Tujuan Penelitian ini untuk mengetahui pengaruh penggantian sebagian ransum basal dengan tepung daun pepaya terhadap persentase karkas dan lemak abdomen ayam pedaging.

\section{MATERI DAN METODE PENELITIAN}

Penelitian ini menggunakan 80 ekor ternak ayam pedaging unsexed, umur 1 hari (DOC). Peralatan yang digunakan seperti, kandang, lampu pijar, kipas angin, tempat makan-minum, koran bekas, dan ember, kandang baterai sebanyak 20 unit, setiap kandang ditempati 5 ekor ayam pedaging. Kandungan nutrien dan energi metabolis bahan pakan penyusun ransum dapat dilihat pada Tabel 1. Pada Tabel 2, komposisi bahan pakan penyusun ransum basal. Tabel 3 adalah susunan ransum perlakuan serta komposisi nutrien dan energi. Rancangan percobaan yang digunakan yaitu Rancangan Acak Lengkap (Steel and Torrie, 1994) dengan 4 perlakuan dan 5 ulangan. Susunan perlakuan sebagai berikut: $\mathrm{R} 0=100 \%$ ransum basal, $\mathrm{R} 1=95 \%$ ransum basal, $5 \%$ tepung daun pepaya, $\mathrm{R} 2=90 \%$ ransum basal, $10 \%$ tepung daun pepaya, $\mathrm{R} 3=85 \%$ ransum basal, $15 \%$ tepung daun pepaya. Uji lanjut dilakukan untuk variabel-variabel yang analisis keragamannya, berbeda nyata dengan menggunakan Uji Beda Nyata Jujur (BNJ). Variabel yang diukur pada penelitian ini, yaitu bobot dan persentase karkas, serta persentase lemak abdominal ayam pedaging. 
Tabel 1. Kandungan Nutrien dan Energi Metabolis Bahan Pakan Penyusun Ransum

\begin{tabular}{lllllll}
\hline Bahan Makanan & $\begin{array}{l}\text { Protein } \\
(\%)\end{array}$ & $\begin{array}{l}\text { Serat } \\
\text { Kasar } \\
(\%)\end{array}$ & $\begin{array}{l}\text { Lemak } \\
(\%)\end{array}$ & $\begin{array}{l}\mathrm{Ca} \\
(\%)\end{array}$ & $\begin{array}{l}\text { P } \\
(\%)\end{array}$ & $\begin{array}{l}\text { EM } \\
(\mathrm{Kcal} / \mathrm{kg})\end{array}$ \\
\hline Jagung* & 8,01 & 3,45 & 7,71 & 0,17 & 0,7 & 2865,75 \\
Tepung Ikan* & 63,6 & 0,5 & 9,3 & 5,81 & 3,23 & 2830 \\
Tepung Kedelai* & 42,02 & 6,4 & 13,22 & 0,21 & 0,65 & 3603 \\
Bungkil Kelapa* & 20,55 & 15,88 & 15,07 & 0,21 & 0,49 & 3724,5 \\
Dedak Halus* & 8,36 & 16,53 & 6,58 & 0,18 & 0,84 & 2564,25 \\
Top Mix & - & 0 & 0 & 5,38 & 1,44 & 0 \\
Minyak & - & 0 & 100 & 0 & 0 & 8812 \\
Tepung Daun Pepaya** & 18,14 & 12,67 & 1,67 & 4,57 & 0,38 & 2476,5 \\
\hline Kenan
\end{tabular}

Keterangan: * Salombre, et al. (2018)

** Analisis Laboratorium Nutrisi Ternak \& Kimia Makanan Ternak, UNPAD 2018

Tabel 2. Komposisi Bahan Pakan Penyusun Ransum Basal

\begin{tabular}{llllllll}
\hline Bahan Makanan & $\begin{array}{l}\text { Penggunaan } \\
(\%)\end{array}$ & $\begin{array}{l}\text { Protein } \\
(\%)\end{array}$ & $\begin{array}{l}\text { SK } \\
(\%)\end{array}$ & $\begin{array}{l}\text { LK } \\
(\%)\end{array}$ & $\begin{array}{l}\text { Ca } \\
(\%)\end{array}$ & $\begin{array}{l}\text { P } \\
(\%)\end{array}$ & $\begin{array}{l}\text { EM } \\
\text { Kcal/kg }\end{array}$ \\
\hline Jagung & 50 & 4,01 & 1,73 & 3,86 & 0,09 & 0,35 & 1432,88 \\
Tepung Ikan & 15 & 9,54 & 0,08 & 1,4 & 0,87 & 0,48 & 424,5 \\
Bungkil kedelai & 14 & 5,88 & 0,9 & 1,85 & 0,03 & 0,09 & 504,42 \\
Bungkil Kelapa & 14 & 2,88 & 2,22 & 2,11 & 0,03 & 0,07 & 521,43 \\
Dedak Halus & 5,5 & 0,46 & 0,91 & 0,36 & 0,01 & 0,05 & 141,03 \\
Top Mix & 0,5 & 0 & 0 & 0 & 0,03 & 0,01 & 0 \\
Minyak & 1 & 0 & 0 & 1 & 0 & 0 & 88,12 \\
\hline Jumlah & 100 & 22,76 & 5,83 & 1,57 & 1,05 & 1,05 & 311,38 \\
\hline
\end{tabular}

Tabel 3. Susunan Ransum Perlakuan serta Komposisi Nutrien dan Energi Metabolis

\begin{tabular}{lllll}
\hline & $\mathrm{R} 0$ & $\mathrm{R} 1$ & $\mathrm{R} 2$ & $\mathrm{R} 3$ \\
\hline $\begin{array}{l}\text { Ransum Basal (\%) } \\
\begin{array}{l}\text { Tepung Daun Pepaya } \\
\text { (TDP) }\end{array}\end{array}$ & 100 & 95 & 90 & 85 \\
Total & 0 & 5 & 10 & 15 \\
\hline & $\mathbf{1 0 0}$ & $\mathbf{1 0 0}$ & $\mathbf{1 0 0}$ & $\mathbf{1 0 0}$ \\
Zat-Zat Makanan* & & & & \\
\hline Protein(\%) & 22,76 & 22,53 & 22,30 & 22,07 \\
Serat Kasar(\%) & 5,83 & 6,17 & 6,51 & 6,85 \\
Lemak(\%) & 10,57 & 10,13 & 9,68 & 9,24 \\
Ca(\%) & 1,05 & 1,23 & 1,40 & 1,58 \\
P(\%) & 1,05 & 1,01 & 0,98 & 0.95 \\
EM(Kcal/kg) & 3112,38 & 3080,58 & 3048,79 & 3016,00 \\
\hline
\end{tabular}

*Dihitung berdasarkan Tabel 1 dan Tabel 2. 


\section{HASIL DAN PEMBAHASAN}

\section{Bobot Karkas}

Hasil analisis sidik ragam menunjukkan bahwa perlakuan penggunaan tepung daun pepaya (carica papaya l) sebagai pengganti sebagian ransum basal memberikan pengaruh berbeda tidak nyata $(\mathrm{P}>0,05)$ terhadap bobot karkas. Hal ini berarti penggunaan tepung daun pepaya sampai $15 \%$ sebagai pengganti sebagian ransum basal, memberikan pengaruh yang sama terhadap bobot karkas atau respon ayam pedaging terhadap ransum perlakuan sampai $15 \%$ sama. Tidak berbedanya bobot karkas pada penelitian ini karena ransum perlakuan mengandung zat-zat makanan yang hampir sama.

Bobot karkas dipengaruhi oleh bobot hidup, sehingga bobot hidup yang besar akan diikuti oleh bobot karkas yang besar. Tingginya bobot karkas ditunjang oleh bobot hidup akhir sebagai akibat pertambahan bobot hidup ternak (Qurniawan et al., 2016). Bobot karkas yang dihasilkan dipengaruhi oleh beberapa faktor yaitu umur, jenis kelamin, bobot potong, besar dan konformasi tubuh, perlemakan, kualitas dan kuantitas ransum, serta strain (Hermawati, 2010). Suprijatna (2010) menyatakan bahwa agar pertumbuhan dan produksi maksimal, jumlah dan kandungan zat-zat makanan yang diperlukan ternak harus memadai.

\section{Persentase Karkas}

Hasil analisis sidik ragam menunjukkan bahwa perlakuan pemberian tepung daun pepaya dalam ransum memberikan pengaruh berbeda sangat nyata $(\mathrm{P}<0,01)$. Hasil uji Beda Nyata Jujur menunjukkan R0 berbeda sangat nyata $(\mathrm{P}<0,01)$ dengan R3 tetapi berbeda tidak nyata $(\mathrm{P}>0,05)$ dengan R2 dan R1. Perlakuan R1 berbeda nyata $(\mathrm{P}<0,05)$ dengan $\mathrm{R} 3$ namun berbeda tidak nyata $(\mathrm{P}>0,05)$ dengan $\mathrm{R} 2$, sedangkan antara perlakuan R2 dan R3 berbeda nyata $(\mathrm{P}<0,05)$. Kisaran persentase karkas pada penelitian ini sejalan dengan pernyataan Mahfudz (2006), yaitu persentase karkas berkisar $65 \%$ - 75\%, sedangkan menurut Sufiriyanto dan Indradji (2007) rataan persentase karkas ayam pedaging umur 5 minggu adalah 59\% - 63\% dari berat hidup.

Menurut Septiani et al. (2016) bahwa ada hubungan linier antara protein, energi, dan persentase karkas. Protein dan energi yang terkandung dalam pakan akan digunakan untuk memproduksi daging dalam tubuh. Persentase karkas sangat ditentukan oleh bobot hidup akhir, bobot potong, dan bobot karkas. Persentase karkas merupakan faktor terpenting untuk menilai produksi ternak, karena erat hubungannya dengan bobot hidup. Semakin bertambahnya bobot hidup, maka 
Tabel 4. Rataan Bobot Dan Persentase Karkas, Serta Persentase Lemak Abdomen Ayam Pedaging Dari Masing-Masing Perlakuan

\begin{tabular}{lcccc}
\hline Variabel & \multicolumn{4}{c}{ Perlakuan } \\
\cline { 2 - 5 } & R0 & R1 & R2 & R3 \\
\hline Bobot Karkas(g) & 750 & 735,6 & 635,4 & 698,4 \\
Persentase Karkas(\%) & $67,62^{\mathrm{a}}$ & $71,31^{\mathrm{a}}$ & $71,49^{\mathrm{a}}$ & $72,91^{\mathrm{b}}$ \\
Persentase Lemak Abdomen $(\%)$ & 2,44 & 2,28 & 2,20 & 1,38 \\
\hline
\end{tabular}

Keterangan: Superskrip berbeda pada garis yang sama menunjukkan berbeda sangat nyata $(\mathrm{P}<0,05)$

produksi karkasnya semakin meningkat (Citrawidi et al., 2012).

Kualitas karkas dinilai berdasarkan keempukan daging, bobot karkas dan tingkat perlemakan (Akhadiarto, 2010). Persentase karkas dipengaruhi oleh bangsa, umur, jenis kelamin, bobot hidup dan makanan. Ayam yang bobot tubuhnya tinggi menghasilkan persentase karkas yang tinggi, sebaliknya ayam yang bobot hidupnya rendah akan menghasilkan persentase karkas yang rendah (Soeparno, 2009).

\section{Persentase Lemak Abdomen}

Rataan persentase lemak abdomen selama penelitian masing-masing perlakuan yaitu, R0 (2,44\%), R1 (2,28\%), R2 (2,20\%) dan R3 (1,38\%). Persentase lemak abdominal tertinggi berada pada R0 $(2,44 \%)$ dan terus menurun hingga pada perlakuan R3 (1,38\%). Persentase lemak abdominal ini, sesuai dengan hasil penelitian dari Pratikno (2012) yaitu, rataan persentase lemak abdomen ayam pedaging berkisar antara 2,49\% - 2,50\%. Pudjiastuti dan Hernawan (2012), menyatakan bahwa persentase lemak abdominal ayam pedaging berkisar antara $0,73-3,78 \%$ dari bobot hidup. Hasil analisis sidik ragam menunjukkan bahwa perlakuan pemberian tepung daun pepaya dalam ransum berpengaruh tidak nyata $(\mathrm{P}>0,05)$. Tidak adanya perbedaan yang nyata disebabkan karena kandungan energi dan protein dalam ransum hampir sama, sehingga tidak terjadi kelebihan energi yang berdampak pada tidak terjadinya penimbunan lemak. Walaupun terdapat perbedaan tidak nyata, namun ada kecenderungan. Penurunan persentase lemak abdomen pada penelitian ini diduga karena kadar serat kasar ransum yang semakin meningkat pada setiap perlakuan (Tabel 3).

Menurut Sarikhan et al. (2010) bahwa ayam yang mengkonsumsi ransum yang mengandung serat kasar yang lebih tinggi mempunyai kandungan lemak 
abdomen yang lebih rendah dibandingkan dengan ransum yang memiliki serat kasar yang lebih rendah. Rendahnya persentase lemak abdomen yang dihasilkan menunjukkan bahwa kondisi perlemakan yang dihasilkan cenderung lebih baik. (Santoso dan Fenita 2015) menyatakan bahwa kandungan alkaloid dan papain pada daun pepaya mampu menurunkan penimbunan lemak pada ayam dan tikus.

\section{KESIMPULAN}

Berdasarkan hasil penelitian ini dapat disimpulkan bahwa penggunaan tepung daun pepaya (carica papaya $l$ ) sampai level $15 \%$ dapat menghasilkan persentase karkas dan lemak abdomen yang baik.

\section{DAFTAR PUSTAKA}

Akhadiarto, S. 2010. Pengaruh pemberian probiotik temban, Biovet dan biolacto terhadap persentase karkas, bobot lemak abdomen dan organ dalam ayam broiler. Jurnal Sains dan Teknologi Indonesia 12(1): 53-59.

Badan Standardisasi Nasional. 2009. [SNI 01-4869-1997] Potongan Karkas Broiler. Badan Standarisasi Nasional, Jakarta.

Citrawidi, T.A., W. Murningsih, dan V. D. Y. B. Ismadi. 2012. Pengaruh pemeraman ransum dengan sari daun pepaya terhadap kolesterol darah dan lemak total ayam broiler. Animal Agriculture Journal 1(1): $529-540$.

Ha, M., A.E.D.A. Bekhit, A. Carne, and D. L. Hopkins, 2012. Characterisation of commercial papain, bromelin, actinidin and zingibain protease preparation and their activities toward meat proteins. J. Food Chemistry 134(1): 95-105

Hermawati, H. 2010. Bobot organ-organ tubuh pada ayam pedaging yang diberi pakan mengandung Minyak Biji Saga (Adenanthera pavonina l). Prosiding. Seminar Nasional Teknologi Peternakan Dan Veteriner. 670-673.

Mahfudz, L. D. 2006. Aktifitas oncom ampas tahu sebagai bahan ransum broiler. J Anim Prod. 8:108-114.

Pudjiastuti, T. O. dan E. Hernawan. 2012. Utilizing of banana peel (musa sapientum) in the ration and its influence on final body weight, percentage of carcass and abdominal fat on broilers under heat stress condition. J. Lucrari Stiintifice - Seria Zootehnie 57:104-109.

Pratikno, H. 2012. Lemak abdominal ayam broiler (Gallus sp.) karena pegaruh ekstrak kunyit ( Curcuma domestica vahl). Bioma 13(1): 17-24.

Qurniawan, A., I.I. Arief, dan R. Afnan. 2016. Performans produksi ayam pedaging pada lingkungan pemeliharaan dengan ketinggian yang berbeda di Sulawesi Selatan. Jurnal Veteriner 17(4): 622-633.

Sarikhan, M., H.A. Shahryar, B. Gholizadeh, M.H. Hosseinzadeh, B. Beheshti, dan A. Mahmoodnejab. 2010. Effects of insoluble fiber on 
growth performance, carcass traits and ileum morphological parameters on broiler chick males. Int. J. Agic Biol. 12:531-536.

Santoso, U. dan Y. Fenita. 2015. Pengaruh Pemberian tepung daun pepaya (carica papaya) terhadap kadar protein dan lemak pada telur puyuh. Jurnal Sains Peternakan Indonesia 10(2): 71-76.

Salombre, V.J., M. Najoan, F.N. Sompie, dan M.R. Imbar. 2018. Pengaruh penggunaan silase kulit pisang kepok (musa paradisiaca formatypica) sebagai pengganti sebagian jagung terhadap karkas dan viscera broiler. Zootec 38(1): 27-36.

Sufiriyanto dan M. Indradji, 2007. Efektivitas pemberian ekstrak temulawak (Curcumaexanthoriza) dan kunyit (Curcumaedomestica) dan sebagai immunostimulator flu burung pada ayam niaga pedaging. J. Animal Production 9: 178-183.
Suprijatna, E. 2010. Strategi pengembangan ayam lokal berbasis sumber daya lokal dan berwawasan lingkungan. Prosiding Seminar Nasional Unggas Lokal ke IV. Hal. 55-79.

Septiani, A. S., O. Sjofjan, dan H. Djunaidi. 2016. Pengaruh beberapa jenis pakan komersial terhadap kinerja produksi kuantitatif dan kualitatif ayam pedaging. Buletin Peternakan 40(3): 187-196.

Soeparno. 2009. Ilmu dan Teknologi Daging. Cetakan Kelima. Gajah Mada University Press. Yogyakarta.

Steel, R. G. D. dan J. A. Torrie. 1994. Principles and Procedures of Statistics. Mcgraw-Hill, New York. 